\title{
Developmental Changes in Rat Liver Xanthine Oxidase(s) and Its Intracellular Distribution
}

\author{
Shigebumi Hashimoto \\ Life Sciences Laboratories, Ajinomoto Co., Inc., 214, Maeda-cho, Totsuka-ku, Yokohama, Japan
}

Received April 17, 1974

\begin{abstract}
Developmental change and subcellular distribution of xanthine oxidase in the rat liver were examined.

The specific activity of the fetal liver xanthine oxidase increased sharply to the levels of the adult liver on the day of the birth. After birth, the activity dropped rapidly and on the 14th day after birth it was about $1 / 4$ of adult level. Then the activity was regained and around 28 th day after birth it was about the same as in adult level.

In the livers from 80 days old rats, about $60 \%$ of total xanthine oxidase activity was found in soluble fraction and the rest was distributed among particulate fractions including microsomal, lysosomal, mitochondrial and nuclear fractions.

In contrast to the adult livers $80 \%$ of total xanthine oxidase activity in fetal liver was found to be in particulate fractions.

From kinetic studies of xanthine oxidases in particulate and soluble fractions it was suggested that xanthine oxidase in soluble fraction and xanthine oxidase in particulate fraction might be different in their natures of protein molecule.
\end{abstract}

Recently, findings on the metabolic changes during the growth have been accumulated. Metabolism of glucose, ${ }^{1,2)}$ glycogen, ${ }^{1 \sim 31}$ tryptophan, ${ }^{4)}$ histidine, ${ }^{5)}$ tyrosine, ${ }^{6)}$ protein, ${ }^{7 \sim 8)}$ and nucleic acid ${ }^{90}$ in the neonatal rat liver changed abruptly on/after birth, adaptatively to extrauterine life. ${ }^{11)}$

Xanthine oxidase (EC 1.2.3.2) (XO) and some of other purine metabolizing enzymes such as guanase, ${ }^{12)}$ hypoxanthinephosphoribosyltransferase, ${ }^{13)}$ uricase, ${ }^{14)}$ and xanthine dehydrogenase $\mathrm{e}^{15 \sim 18)}$ are all examples, showing marked change in their activities on/after birth.

We have been studying on the developmental pattern in metabolism of exogenous purines in rats, focused on its terminal reactions. And we reported the developmental pattern of rat liver XO from the view point of activity and intracellular distribution.

\section{MATERIALS AND METHOD}

Animals. Wistar strain male rats of various ages bred in our laboratory were used in this study. All the animals were kept in an air-conditioned room where temperature was maintained at $23 \pm 2^{\circ} \mathrm{C}$ with the relative humidity at $5 \pm 10 \%$. And they were fed a laboratory chow (CE-2 from CLEA Japan Inc.) and water ad libitum. Male pre-natal rats used in the study were delivered by hysterotomy.

Chemicals and reagents. Xanthine, uric acid and allopurinol were purchased from Sigma Chemicals Co. Potassium 2,4-dihydroxy-6-carboxy-1,3,5-triazine (Potassium oxonate), which was synthesized by Brandenberger's method, ${ }^{19)}$ was kindly supplied by Dr. D. Suzuki of central Res. Lab., Ajinomoto Co., Inc. Anal. Found: C, 24.60; H, 1.25; N, 21.10. Calcd. for $\mathrm{C}_{4} \mathrm{H}_{2} \mathrm{O}_{4} \mathrm{~N}_{3} \mathrm{~K}: \mathrm{C}, 24.61 ; \mathrm{H}, 1.04 ; \mathrm{N}, 21.53 \%$. All other chemicals were of reagent grade.

Preparation of rat liver homogenate and subcellular fractionation. Male pre-and-post-natal rats of various ages were sacrificed by decapitation, and the liver was removed immediatelly and homogenized with 9 vol. of cold $0.25 \mathrm{M}$ sucrose solution in a Potter-Elvehjem homogenizer with a teflon pestle.

Liver homogenate was centrifuged at $100,000 \times g$ for $60 \mathrm{~min}$ at $0^{\circ} \mathrm{C}$. XO in the supernatant solution from liver homogenate after centrifugation at $100,000 \times g$ for $60 \mathrm{~min}$ was denoted as $\mathrm{XO}_{\mathrm{s}}$ and $\mathrm{XO}$ in the sediment was denoted as $\mathrm{XO}_{\mathrm{p}}$.

Nuclear, mitochondrial, lysosomal and microsomal fractions and a soluble fraction were prepared by the centrifugal method of De Duve et al. ${ }^{201}$ 
Enzyme assays. XO activity was measured spectrophotometrically (S. Hashimoto*) by the increase in absorbancy at $300 \mathrm{~nm}$, which depends upon uric acid from xanthine, at $30^{\circ} \mathrm{C}$ in the enzyme preparation of rat liver adding potassium oxonate, a specific uricase inhibitor, to the medium so as to exclude interferance owing to uricase coexisted. One unit of XO activity in an amount of enzyme which catalyses the formation of one $\mu$ mole of uric acid per minute under the assay condition.

Uricase activity was measured spectrophotometrically ${ }^{21}$ ) by the elimination of uric acid through the decrease in absorbancy at $292 \mathrm{~nm}$ at $25^{\circ} \mathrm{C}$.

Protein was determined by the method of Lowry et al. ${ }^{22)}$ with bovine serum albumin as a standard.

\section{RESULTS AND DISCUSSION}

\section{Enzyme assay}

The adequacy of enzyme used in this study is indicated in Fig. 1 where there was direct proportionality between $O D$ and the quantity of enzyme present. Only results from adult liver homogenate are presented in Fig. 1, but other enzyme preparations showed essentially similar proportionality.

Since $\mathrm{XO}$ in mouse liver homogenate was

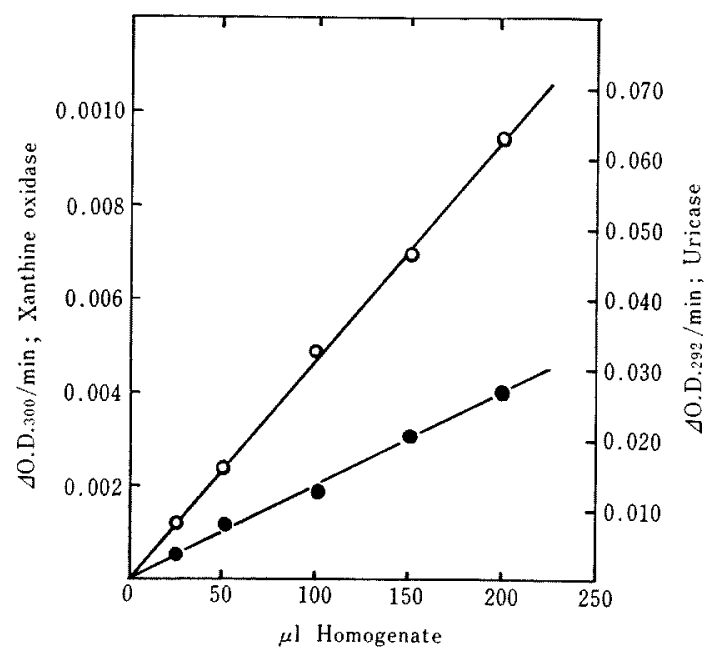

FIG. 1. Assay of Xanthine Oxidase and Uricase in the Rat Liver Homogenate.

Each point represents the average of three independent assays from the same liver homogenate.

$\bigcirc-0$, Uricase activity; $-\bullet$, Xanthine oxidase activity.

* Details will be reported separately. shown to increase in activity substantially by preincubation under some conditions, ${ }^{23)}$ the XO activities in rat liver homogenate were assayed before and after preincubation under essentially the same condition $\left(0^{\circ} \mathrm{C}\right.$ for days or $25^{\circ} \mathrm{C}$ for hours). It was found that the detectable $\mathrm{XO}$ activity nearly doubled after preincubation at $25^{\circ} \mathrm{C}$. Further studies showed that the same increase in activities could also be obtained if homogenate were incubated with $0.05 \%$ Triton $\mathrm{X}-100$ at $0^{\circ} \mathrm{C}$ for approx. $20 \mathrm{hr}$ or at room temperature for approx. $40 \mathrm{~min}$.

To elucidate whether the increase in XO activity may be attributable to a conversion from xanthine dehydrogenase to xanthine oxidase as reported by Stirpe et al. ${ }^{24)}$ the following experiment was carried out. The rat liver homogenate was incubated aerobically in the $\mathrm{XO}$ assay medium containing $0.7 \mathrm{mM}$ NAD, an effective electron acceptor for xanthine dehydrogenase, before and after preincubation as mentioned above in order to measure sum of XO activities of oxidase type and, if any, dehydrogenase type. It was found that the increase in sum of XO activities under above conditions were not affected by adding NAD to the assay medium. Accordingly, the increase in activities of XO might not be due to a conversion from dehydrogenase type to oxidase type because, if the increase in XO activities had been attributed to the conversion, sum of $\mathrm{XO}$ activities measured in the presence of NAD should not change and increase by preincubations as mentioned above.

The final $\mathrm{XO}$ activities obtained after appropriate treatments of the homogenate are reported.

\section{Developmental changes of $X O$ activities in rat liver}

Figure 2 shows the developmental pattern of XO activity in rat liver. Total activity of hepatic XO was very low in fetal liver and not significantly changed until 14 th day after birth. Thereafter, total activity increased and reached to adult level around 84 days of age.

Specific activity of XO in fetal liver increased sharply towards the day of birth and reached 


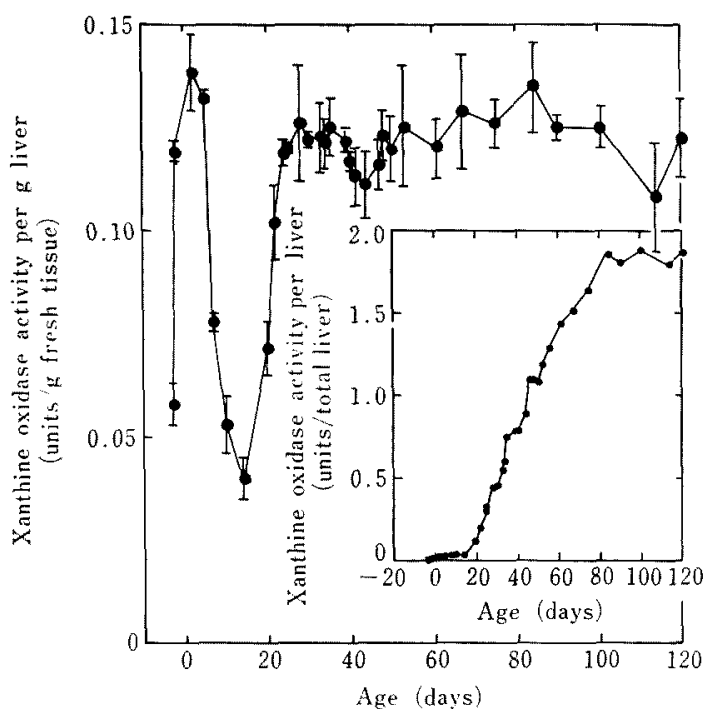

FIG. 2. Developmental Change of Rat Liver Xanthine Oxidase.

Liver was homogenized with 9 vol. of $0.25 \mathrm{M}$ sucrose solution, and the whole homogenate was assayed for $\mathrm{XO}$ activity. The XO activity was measured at $30^{\circ} \mathrm{C}$ in a mixture (final volume of $3 \mathrm{ml}$ ) containing $0.1 \mathrm{M}$

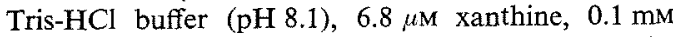
potassium oxonate and $0.2 \mathrm{ml}$ of homogenate. The reaction was stopped by adding $0.1 \mathrm{ml}$ of $100 \%(\mathrm{w} / \mathrm{v})$ trichloroacetic acid the mixture was centrifuged at $10,000 \times g$ for $15 \mathrm{~min}$. With resultant clear supernatant absorption at $300 \mathrm{~nm}$ was measured against mixture without xanthine. Each point represents the mean value of specific activity of XO (units/g fresh tissue) from 5 to 10 rats with the standard error. The inset shows the total activity of XO (units/liver).

to a peak at birth and then the activity dropped sharply to about $1 / 4$ on the 14 th day after birth. Thereafter, the activity regained rapidly and finally reached to the activity level at birth on and after 24 days of age.

The remarkably low activity in liver from rat of 14 th day after birth was not due to the presence of any inhibitor which might mask the detection as reported by Fried et al. ${ }^{25)}$ because homogenates prepared from these livers did not show any inhibition.

Fourteenth day after birth is known to be a critical day for rats, switching their metabolism from neonatal to infantile life..$^{9,13,26}$ ) Our results also emphasized that the 14th day after birth seemed to be a significant day for rats.

These facts suggest that the fetal liver and the adult liver have different types of enzyme: the fetal type XO stopped to develop at birth and the adult type started to develop on and around 14 days of age.

Silverstein et al. ${ }^{27)}$ examined developmental changes of rat liver XO using cytoplasmic preparations obtained by ultra-high speed centrifugation. And it was shown that the specific activity of rat liver XO scarcely increased until the $20 \sim 30$ day period when a sharp rise in activity occured, with little further change thereafter to 60 days of age.

Age dependent pattern of the specific activity of rat liver XO reported here (Fig. 2) was similar to that of Silverstein et al. during the growth stages after 14 days of age. A marked difference is that a peak with high XO activity was observed before the 14th day after birth in present study, on the other hand the XO activity was low and flat until 20 days of age in that of Silverstein et al.

This may be due to the difference of $\mathrm{XO}$ assay preparations. They used only a soluble fraction of rat liver homogenate for assay of XO activity. Thus, the substantial amount of XO activities in particulate fractions of rat liver homogenate seems to be ignored.

Yoshida et $a l^{28}$ reported that the specific activity of rat liver $\mathrm{XO}$ increased to a maximal level at the age of $100 \sim 130$ days after birth, with a gradual decrease thereafter. The time, when an adult level of XO activity was gained, was later by about 90 days than that reported here. The possible reason for this marked difference may be attributable to not only the difference of rats and diets used but also the difference in XO assay procedures. The other difference noted was that on and around the day of birth, a peak with high XO activities was observed here while such a peak was not observed in their study. The possible reason for this difference may be because $\mathrm{XO}$ activities in fetal and neonatal livers were not examined in their study.

\section{Subcellular distribution of $X O$ and uricase}

Figure 3 shows subcellular distribution of $\mathrm{XO}$ and uricase in adult rat livers. $\mathrm{XO}$ ac- 


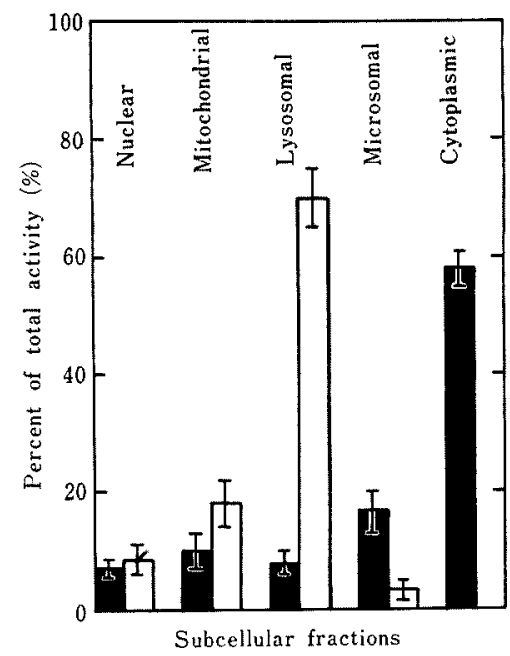

Fig. 3. Subcellular Distribution of Xanthine Oxidase and Uricase in Rat Liver.

Livers of 80 days old rats were homogenized with 9 vol. of $0.25 \mathrm{~m}$ sucrose solution and fractionated by the method of De Duve et al. ${ }^{201}$ Each particulate fraction was span down and rehomogenized with 9 vol. $0.25 \mathrm{M}$ sucrose solution containing $0.05 \%$ Triton $\mathrm{X}-100$ before assay. $\mathrm{XO}$ activity was assayed as described in regend in Fig. 1. Uricase activity was measured spectrophotometrically by the method of Fridovich ${ }^{21}$ in the medium containing $0.1 \mathrm{M}$ borate buffer ( $\mathrm{pH} 8.5$ ), $0.1 \mathrm{~mm}$ uric acid and $0.2 \mathrm{ml}$ of enzyme preparation in $3 \mathrm{ml}$, at $25^{\circ} \mathrm{C}$. The total activity of $\mathrm{XO}$ was $0.13 \pm 0.01 \mu$ mole of uric acid formed $/ \mathrm{min}$ per $g$ liver (mean $\pm S$. E.). Total activity of uricase was $0.96 \pm 0.06 \mu$ mole of uric acid disappeared $/ \mathrm{min}$ per $g$ liver (mean \pm S. E.). Each point represents the mean value for five rats with the standard error. Open bars, uricase activities: shaded bars, XO activities.

tivity was found in every fraction; $60 \%$ of the total activity was found in soluble fraction and the rest was in particulate fractions. Uricase activity was found exclusively in particulate fractions, especially in lysosomal fraction. This agreed well with those of De Duve et al. ${ }^{201}$

Age dependent pattern of distribution of $\mathrm{XO}$ activity in rat livers was shown in Fig. 4.

In fetal liver, about $90 \%$ of the XO activity was in $\mathrm{XO}_{\mathrm{p}}$ and about $10 \%$ of the activity was in $\mathrm{XO}_{\mathrm{s}}$. On the 14th day after birth, $\mathrm{XO}_{\mathrm{s}}$ activity started to increase but most of the activity was still in $\mathrm{XO}_{\mathrm{p}}$. On the 24th day after birth, the activity of $\mathrm{XO}_{\mathrm{s}}$ was higher than that of $\mathrm{XO}_{\mathrm{p}}$. This distribution pattern is closely related to the adult type distribution. By the 41 st day, activity distribution pattern of the adult type was established, i.e. $60 \%$ of the activity was in $\mathrm{XO}_{\mathrm{s}}$ and the rest in $\mathrm{XO}_{\mathrm{p}}$.

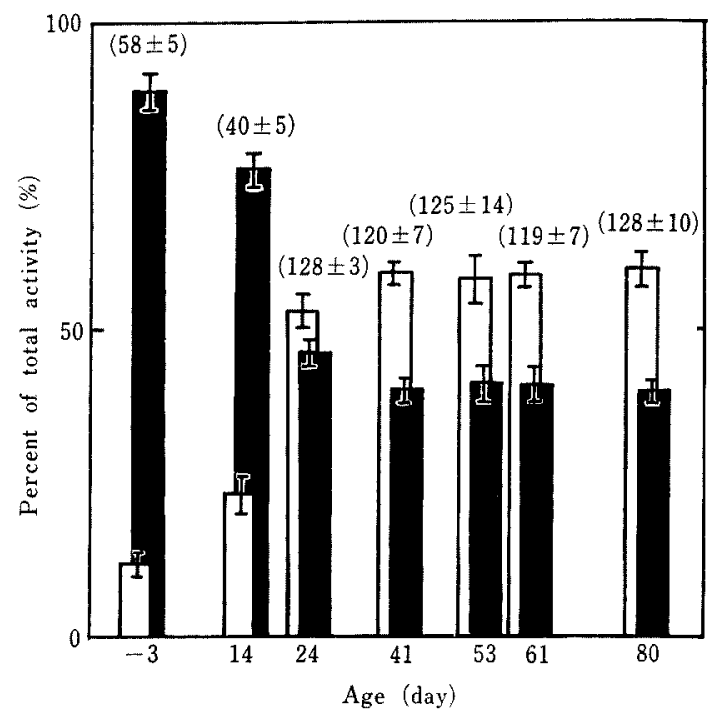

FIG. 4. Developmental Changes of Xanthine Oxidase in Soluble and Particulate Fractions of Rat Liver.

$\mathrm{XO}$ activity was measured as described in regend in Fig. 1. The $\mathrm{XO}$ activities in soluble fraction $\left(\mathrm{XO}_{\mathrm{s}}\right)$ and particulate fraction $\left(\mathrm{XO}_{p}\right)$ were expressed as the precent of total activity in $g$ of liver. Each point represents the mean value for five rats with the standard error. Values in parenthesis indicate the total activity, milli-unit per $g$ liver (mean \pm S. E.). Open bar, $\mathrm{XO}$ activity in soluble fraction $\left(\mathrm{XO}_{\mathrm{s}}\right)$ : shaded bar, $\mathrm{XO}$ activity in particulate fraction $\left(\mathrm{XO}_{\mathrm{p}}\right)$.

From these developmental pattern in rat liver $\mathrm{XO}$, it is suggested that there may be two types of $\mathrm{XO}$ : one is the fetal type, which is present mainly as $\mathrm{XO}_{\mathrm{p}}$, and the other is the adult type, which is mainly present as $\mathrm{XO}_{\mathrm{s}}$.

Kinetic properties of $X O_{p}$ and $X O_{s}$

As seen in Fig. 5, $\mathrm{XO}_{\mathrm{p}}$ and $\mathrm{XO}_{\mathrm{s}}$ differed in their velocity response to increasing substrate concentration. $\mathrm{XO}_{\mathrm{s}}$ responded sigmoidally, with an apparent $K m$ value $14.7 \mu \mathrm{M}$ calculated as $s_{0.5}$ from a Hill-plot $\left(\log v / V_{\max }-v\right.$ versus $\log S$ ), where $s_{0.5}$ is the concentration of substrate giving $50 \%$ of the maximal activity. Whereas $\mathrm{XO}_{\mathrm{p}}$ apparently behaved in a typical 

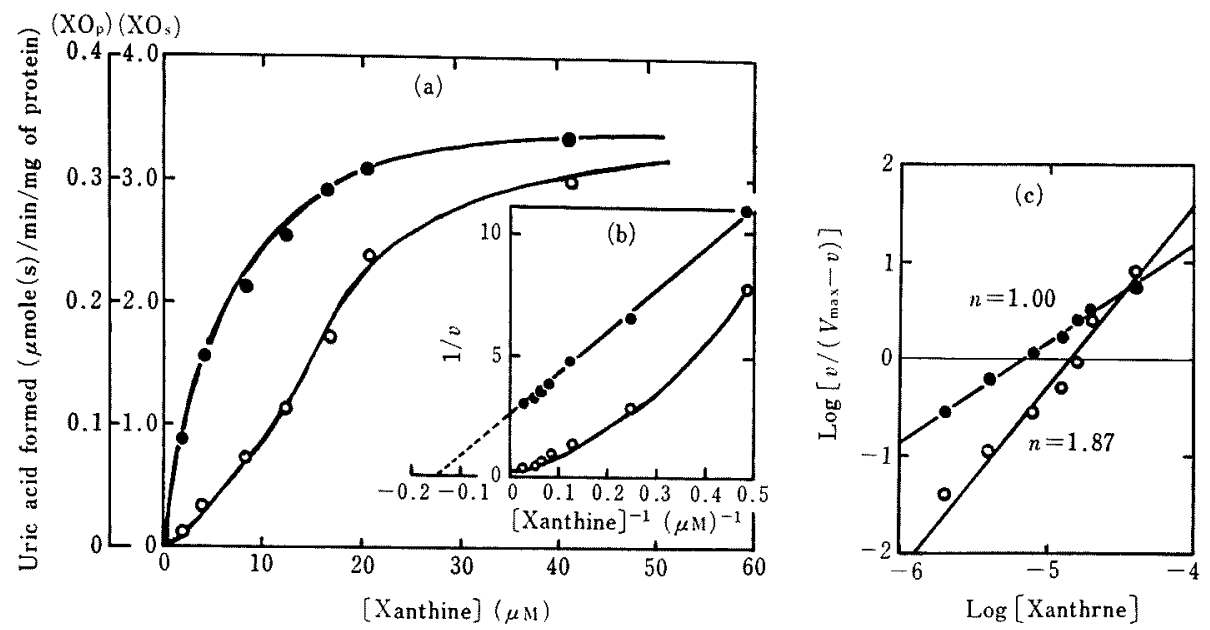

FIG. 5. Substrate Concentration-Reaction Rate Relationship of Rat Liver Xanthine Oxidase(s).

Kinetics were studied with $\mathrm{XO}_{\mathrm{p}}(-\bullet)$ and $\mathrm{XO}_{\mathrm{s}}(\mathrm{O}-\mathrm{O}) . \mathrm{XO}_{\mathrm{p}}$ and $\mathrm{XO}$ were prepared as described in regend in Fig. 3 and these activities were assayed as described in regend in Fig. 2 . (a) $\mathrm{S}-v$ plot; (b) double-reciprocal plot; (c) Hill plot.

hyperbolic manner, with a $K m$ value $6.67 \mu \mathrm{M}$ from a double reciplocal plot or $6.81 \mu \mathrm{M}$ calculated as $s_{0.5}$ from a Hill-plot. The extent of cooperativity as given by the slope of the Hill-plot (Hill coefficient), $n$, was 1.87 for $\mathrm{XO}_{s}$, and 1.00 for $\mathrm{XO}_{\mathrm{p}}$.

Moreover, according to Hill-plot analysis,

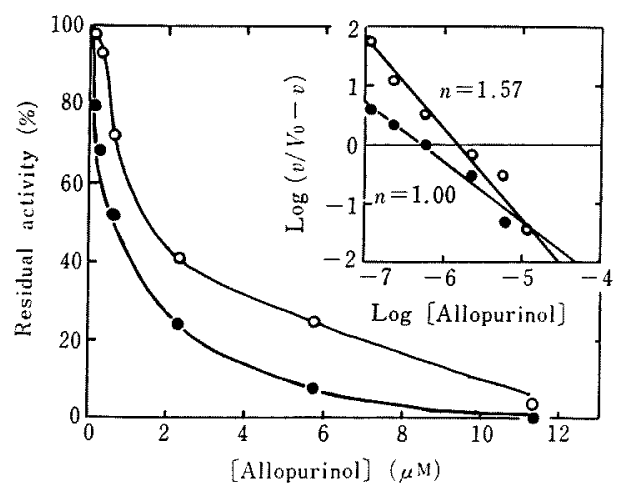

FIG. 6. Inhibition of Rat Liver Xanthine Oxidase(s) Activity by Allopurinol.

Inhibition kinetics were studied with $\mathrm{XO}_{\mathrm{p}}$ and $\mathrm{XO}_{\mathrm{O}}(\mathrm{O})$ at a fixed concentration of substrate, xanthine.

$\mathrm{XO}_{\mathrm{p}}$ and $\mathrm{XO}_{\mathrm{s}}$ were prepared as described in Fig. 3. and these activities were assayed as described in Fig. 2. The inset shows a Hill-plot of the inhibition data, where $V_{0}$ is velocity in the absence of the inhibitor, allopurinol, and $v$ is the observed velocity at a given concentration of the inhibitor. the inhibition of $\mathrm{XO}_{\mathrm{s}}$ activity by allopurinol was sigmoidal $(n=1.57)$, with a $K i$ value $1.6 \mu \mathrm{M}$ calculated as $\mathrm{I}_{0.5}$ from a Hill-plot, where $\mathrm{I}_{0.5}$ is the concentration of inhibitor giving $50 \%$ inhibition, while that of $\mathrm{XO}_{\mathrm{p}}$ activity was classically Michaelian $(n=1.00)$, with a $K i$ value $0.50 \mu \mathrm{M}$ calculated as $\mathrm{I}_{0.5}$ (Fig. 6).

S. Kumar et al. ${ }^{29,30)}$ reported similar observations that there were two types of guanase in rat liver: One was an allosteric protein and the other was a non-allosteric protein. And they considered that the two types of guanase is an isozyme.

These differences in kinetic properties between $\mathrm{XO}_{\mathrm{p}}$ and $\mathrm{XO}_{\mathrm{s}}$ could be atributable not only to their intracellular localization but also to their natures of protein molecule.

To elucidate whether relation between $\mathrm{XO}_{\mathrm{p}}$ and $\mathrm{XO}_{\mathrm{s}}$ is an isozyme or an oligomer of the other enzyme, we need further proof on the difference in nature of the protein molecule.

Acknowledgement. The author is indebted to Dr. J. Kirimura, Mr. M. Sasaoka and Mr. M. Ichimura, in this research laboratories, for their helpful discussion and suggestions in this work.

\section{REFERENCES}

1) H. B. Burch, O. H. Lowry, A. M. Kuhlman, E. 
J. Skerjance, S. R. Lowry and P. Von Dippe, J. Biol. Chem., 238, 2267 (1963).

2) H. B. Burch, Ann. N. Y. Acad.Sci., 111, $176(1963)$

3) M. J. R. Dawkins, ibid., 111, 203 (1963).

4) A. M. Nemeth, J. Biol. Chem., 234, 2921 (1959).

5) G. Kahlson, E. Rosengren and T. White, $J$. Physiol., 151, 131 (1960).

6) N. Kretchmer and H. McNamara, J. Clin. Invest., 35, 1089 (1956).

7) N. B. Burch, O. H. Lowry, T. De Gubareff and S. R. Lowry, J. Cell Comp. Physiol., 52, 503 (1958).

8) A. Lajtha, Int. Rev. Neurobiol., 4, 1 (1962).

9) H. B. Burch and P. Von Dippe, J. Biol. Chem., 239, 1898 (1964).

10) I. T. Oliver and W. F. C. Blumer, Biochem. J., 91, 559 (1964).

11) W. E. Knox, V. H. Auerbach and E. C. C. Lin, Physiol. Rev., 36, 164 (1956).

12) E. Silverstein, O. Zaklynsky and T. Horn, Proc. Soc. Exptl. Biol. Med., 132, 91 (1969).

13) W. Gutensohn and G. Guroff, J. Neurochem., 19, 2139 (1972).

14) R. Donath, Acta Biol. Med. German, 12, 126 (1964).

15) P. C. Lee and J. R. Fisher, Develop. Biol., 25, 149 (1971).

16) J. R. Fisher, J. L. Curtis and W. D. Woodward, ibid., 15, 289 (1967).
17) P. C. Lee and J. R. Fisher, Arch. Biochem. Biophys., 148, 277 (1972).

18) W. D. Woodward and J. R. Fisher, Develop. Biol., 16, 282 (1967).

19) H. Brandenberger, Biochim. Biophys. Acta, 15, 108 (1954).

20) C. De Duve, B. C. Pressman, R. Gianetto, R. Wattiaux and F. Appelmans, Biochem. J., 60 , 604 (1955).

21) I. Fridovich, J. Biol. Chem., 240, 2491 (1965).

22) O. H. Lowry, N. J. Rosebrough, A. L. Farr and R. J. Randall, J. Biol. Chem., 193, 265 (1951).

23) P. C. Lee, Develop. Biol., 31, 227 (1973).

24) F. Stirpe and E. Della Corte, J. Biol. Chem., 244, 3855 (1969).

25) R. Fried, L. W. Fried and D. Babin, Eur. J. Biochem., 16, 399 (1970).

26) M. Winick and A. Noble, Develop. Biol., 12, 451 (1965).

27) E. Silverstein, O. Zaklynsky and T. Horn, Proc. Soc. Exptl. Biol. Med., 132, 91 (1969).

28) A. Yoshida, T. Yamazaki and K. Ashida, Nippon Nógeikagaku Kaishi, 29, 721 (1955).

29) V. Josan and P. S. Krishnan, Biochem. Biophys. Res. Commun., 31, 299 (1968).

30) K. S. Kumar, A. Sitaramayya and P. S. Krishnan, Biochem. J., 128, 1079 (1972). 